\title{
Polygamy Marriage Law Without Court Permits
}

\author{
Mustaqim, Postgraduate Lecturer of Universitas Pakuan Bogor, mustaqimbogor@gmail.com, ORCID.0000- \\ 0009-2675-0564
}

Agus Satory, Postgraduate Lecturer of Universitas Pakuan Bogor, agussatory4@gmail.com, ORCID.00000009-2987-0988

\begin{abstract}
There have been many rules regarding polygamy, but in reality there are still many problems caused by polygamy, both the process in executing the polygamy and the situation after polygamy is implemented or not implemented. The rejection of a request for polygamy will have a special effect on the perpetrators of polygamy. There have been many responses from the community about the rampant polygamy carried out by community leaders so far. With this writing, it is expected that various responses from the community about the prevalence of polygamy carried out by community leaders can also be seen and what legal consequences will arise from the application for polygamy rejected by the religious court of Semarang Regency.By using the empirical juridical approach it is expected to be able to solve problems in research by examining secondary data first to be linked with data in the field. By conducting this research, we will be able to understand things about polygamy and know the consequences that will arise if a polygamy request is rejected by the Court. Therefore it can be concluded that in essence polygamy carried out by anyone is not a problem as long as the perpetrators of polygamy can fulfill the reasons and conditions for polygamy and the legal consequences of rejecting the request for polygamy are the applicants for polygamy continue to carry out a polygamy marriage with a siri marriage or an underhand marriage.
\end{abstract}

Keywords: Legal Consequences, Polygamy, Court Received: $14.12 .2020 \quad$ Accepted: 10.01 .2021 Published: 08.02.2021

\section{INTRODUCTION}

Various principles contained in Law Number 1 of 1974 concerning Marriage, among others, state that the purpose of marriage is to form a happy and eternal family. For this reason, husband and wife need to help and complement each other, so that each of them can develop respective personality to help and achieve spiritual and material well-being. Apart from these principles, Law Number 1 of 1974 concerning Marriage also adheres to the principle of monogamy. Only if accepted by the person concerned, where the law and religion of the person concerned allows, a husband is allowed to have more than one wife. However, a marriage between a husband and more than one wife, even though it is desired by the parties concerned, can only be carried out if certain conditions are met and decided by the Court. The goal of marriage is to form a happy and lasting family. According to Article 1 of Law Number 1 of 1974 concerning Marriage, Marriage is a physical and spiritual bond between a man and a woman as husband and wife with the aim of forming a happy and eternal family (household) based on the One God.

\section{Problems}

1. What is the legal concequence on polygamous marriages that do not get permission from the Court?

2. What is the legal concequence on a polygamous marriage without the permission of the first wife (first wife)?

\section{RESEARCH METHOD}

The approach method used in this research is a normative juridical approach, which is a literature law research conducted by examining library materials or secondary data. Normative juridical approach emphasizes the use of secondary data sources in the form of statutory regulations, legal theories with legal sociology. 
This research is analytical descriptive, which describes the prevailing laws and regulations in relation to legal theories and practices of positive law implementation concerning the above problems. Descriptive in nature, with this research it is expected that a comprehensive and systematic picture will be obtained. It is said to be analytical in nature because based on the descriptions and facts obtained through document study, a careful analysis is then carried out.

\section{DISCUSSION}

The word polygamy comes from Greek which consists of two main words, namely polu and gamein. Polu means a lot, gamein means marriage. Then polygamy means multiple marriages. In Indonesian it is called "Permaduan". In the theory of legal science, polygamy is usually formulated as a system of marriage between a man and more than one woman.

According to Musdah Mulia, that polygamy is a marriage bond in which one party (husband) marries several (more than one) wives at the same time.

Regarding marriage in Law No. 1 of 1974 there are principles stated in this law, among others, are as follows: A marriage is legal if it is carried out according to the law of each religion and belief and besides that each marriage must be recorded according to the prevailing laws and regulations. The registration of every marriage is as any important events, for example a birth, death stated in certificates, an official certificate which is also included in the registration. This law adheres to the principle of monogamy, only if accepted by the person concerned, because the law and religion of the person concerned allows it, a husband may have more than one wife. However, a marriage between a husband and more than one wife, even if it is desired by the parties concerned, can only be carried out if certain conditions are met and decided by the Court. Furthermore, based on Article 3 (1) of Law Number 1 of 1974 concerning Marriage, in principle, in a marriage a man may only have one wife. A woman can only have one husband. However, according to paragraph (2) the court can give permission for a husband to have more than one wife if the parties concerned wish to do so. Thus, it is possible for a husband to have more than one wife if the court gives permission for the husband to have more than one wife.

In the event that a husband will have more than one wife, as stated in Article 3 paragraph (2) of Law No.1 of 1974, then he is obliged to submit a request to the Court in the area where he lives. Furthermore, in paragraph (2) it is stipulated that the Court only gives permission to a husband who will have more than one wife if :

a. The wife could not carry out her obligations as a wife;

b. The wife has a disability or an incurable disease;

c. The wife could not bear offspring.

Then to be able to submit a request to the Court, the following conditions must be met:

a.an agreement from the wife / wives is reached;

b. there is certainty that the husband is able to provide for the living necessities of his wife and children;

c.there is a guarantee that the husband will treat his wives and children fairly.

However, in connection with this matter, Law No.1 of 1974 provides an exception, namely that consent is not required for a husband if his wife / wives has not way to be asked for her consent and unable to be parties to the agreement, or if there is no updated information from his wife for at least -a minimum of 2 (two) years, or due to other reasons that need to be assessed by the Court Judge.

Based on these various legal provisions, marriage with more than one woman is allowed according to Law No.1 of 1974, but must meet various requirements stipulated by the applicable legal regulations. Likewise, only if the person concerned wishes to do so, because the law and religion of the person concerned allows it, a husband may have more than one wife. However, a marriage between a husband and more than one wife, even though it is desired by the parties concerned, can only be carried out if certain conditions are met and decided by the Court.

\section{Polygamy Implementation Procedure}

The procedure for executing polygamy is regulated in Article 40 of Government Regulation No. 9/1975 which stipulates that: "If a husband intends to have more than one wife, then he is obliged to submit a written request to the Court". This is also regulated in Articles 56, 57 and 58 of the Compilation of Islamic Law as follows:

Article 56 Compilation of Islamic Law as follows:

(1) Husbands who wish to have more than one wife must obtain permission from the Religious Court.

(2) Submission of a permit as referred to in paragraph (1) shall be carried out according to the procedure as stipulated in Chapter VIII of Government Regulation Number 9 of 1975. 
(3) A marriage carried out with his second, third or fourth wife without permission from the Religious Court is not legally enforceable.

Article 57 Compilation of Islamic Law:

The Religious Courts only give permission to husbands who will have more than one wife if:

a. The wife is unable to fulfill her obligations as a wife;

b. The wife has a disability or an incurable disease;

c. The wife is unable bear offspring.

The three reasons are alternative in nature where only one option that essentially to be fulfilled for polygamy, because if the three reasons must be fulfilled, it is impossible for people to practice polygamy. If the Religious Court has received a polygamy permit, then it will examine it under Article 57 Compilation of Islamic Law:

A. whether there is a reason that allows a husband to remarry;

B. whether or not the consent of the wife is there, either oral or written, if the agreement is an oral agreement, that agreement must be pronounced before a court session;

C. whether or not the husband's ability to provide for the living needs of his wife and children, by showing:

i. a statement letter regarding the husband's income signed by the treasurer of the workplace, or

ii. income tax certificate, or

iii. other certificate acceptable to the court.

Article 58 paragraph (2) Compilation of Islamic Law without prejudice to the provisions of Article 41 letter b Government Regulation Number 9 of 1975, the consent of the wife or wives can be given in writing or orally, but even if there is a written consent, this agreement is confirmed by an oral agreement of the wife at the Religious Court hearing.

Furthermore, the technical procedures for examination according to Article 42 of Government Regulation Number 9 of 1975 are as follows:

(1) In examining the matters in Articles 40 and 41, the court must summon and hear the wife concerned.

(2) Court examination for this purpose shall be carried out by a judge no later than 30 (thirty) days after the receipt of the permit letter and its attachments.

Therefore, in conducting an examination of the matters in Articles 40 and 41, the Court must summon and hear the wife concerned. If something happens or another thing or the wife has no way to be asked for her consent or unable to be a party to the agreement, then Law Number 1 Year 1974 Concerning Marriage Article 5 paragraph (2) confirms:

The consent referred to in paragraph (1) letter a of this article is not required for a husband if his wife / wives cannot possibly be asked for her consent, and unable to be a party to the agreement, or if there is no news from his wives for at least 2 (two) years or for other reasons that need to be assessed by the Court Judge, but if the Court is of the opinion that there is sufficient reason for the applicant to have more than one consistency, the court will give its decision to have more than one consistency in the form of permission (Article 43 of Government Regulation Number. 9 of 1975). So basically the court can give permission for a husband to have more than one wife if they meet the requirements for obtaining Court permission.

Article 3 paragraph (2) Law Number 1 Year 1974 Concerning Marriage, in the event that the wife does not want to give consent, and the request for permission to marry more than one person is based on one of the reasons stipulated in Article 55 paragraph (2) and Article 57 Compilation of Islamic law, the religious court can determine the granting of permission after examining and hearing the wife concerned at the trial of the Religious Court, and against this decision the wife or husband can file an appeal or cassation (Compilation of Islamic Law).

Then, Article 43 of Government Regulation Number 9 of 1975 stipulates that:

If the court suggests that there is sufficient reason for the applicant to have more than one wife, the court will give a decision in the form of permission to have more than one wife. In Article 44 of Government Regulation Number 9 of 1975 Registration Employees are prohibited from registering the marriage of a husband who will have more than one wife prior to the Court's permission as referred to in Article 43 of Government Regulation Number 9 of 1975.

Thus, the legal provisions governing the implementation of polygamy as stated are binding on all parties, parties who will carry out polygamy and employees of marriage registries. If they violate the provisions of these articles, they will be subject to criminal sanctions. This is regulated in Chapter IX Article 45 of Government Regulation Number 9 of 1975 as follows:

(1) Unless otherwise stated in the prevailing laws and regulations, then: 
a. Anyone who violates the provisions stipulated in Article 3, Article 10 paragraph (3), 40 of this Government Regulation will be punished with a fine of up to Rp. 7,500 (seven thousand and five hundred rupiah);

b. Registration employees who violate the provisions stipulated in Articles 6, 7, 8, 9, 10 paragraphs (1), 11, 12 and 44 of this Government Regulation are punished with a maximum imprisonment of 3 (three) months or a maximum fine of Rp. 7,500,-(seven thousand five hundred rupiah) (2) The criminal act referred to in paragraph (1) above constitutes a violation.

Regarding filing an application to the Court, it is regulated in Article 5 (1) of Law No.1 of 1974 concerning Marriage, that to be able to submit an application to the Court, the following conditions must be fulfilled:

a. there is agreement from the wife / wives;

b. there is certainty that the husband is able to provide for the living necessities of his wife and children;

c. there is a guarantee that the husband will treat his wives and children fairly.

(2) The consent referred to in paragraph (1) letter a of this article is not required for a husband if his wife / wives cannot be asked for their consent and unable to become parties to the agreement, or if there is no news from his wife for at least 2 (two). years, or for other reasons that need to be assessed by the Court Judge.

The provisions of the law on polygamy that can be carried out at the will of the person concerned through the permission of the Religious Court after it has been proven that the benefit is the realization of the ideals and goals of the marriage itself, namely an eternal household blessed by Allah SWT and is based on love and compassion. Therefore all possible problems will become an obstacle to the realization of the marriage goal must be eliminated or at least reduced. Nevertheless polygamy is only limited to 4 (four) wives, as confirmed in Article 55 of the Compilation of Islamic Law as follows:

(1) To have more than one wife at the same time is limited to four wives.

(2) The main condition for having more than one wife is that the husband must be able to treat his wives and children fairly.

(3) If it is impossible to fulfill the main conditions mentioned in paragraph (2), the husband is prohibited from having more than one wife.

\section{Legal consequences of marriage without court permission}

As has been stated that permission from the court to carry out polygamy is a condition that must be met so that a husband can practice polygamy, if this permission has been obtained then a polygamous marriage can be carried out, therefore the marriage can also be registered with the Marriage Registry Officer. However, even without permission from the court, a husband can still practice polygamy and a marriage from polygamy is still legal according to Islamic law and according to the marriage law. However, even though the marriage is valid, it cannot be registered at the Marriage Registry Office. Such a marriage is commonly referred to as a siri marriage or an underhand marriage. Therefore this marriage cannot be registered at the Marriage Registration Office, therefore the state does not recognize the marriage. If in the future problems arise in this marriage, the state official concerned will not intervene in solving the problems arising in the marriage. For example, if the unregistered marriage is broken up due to divorce, the court is not authorized to put such event into trial, because the marriage is not registered with the state through the Marriage Registry Office. Another consequence that will arise in this unregistered marriage is that the children born from that marriage are legitimate children but are also not recognized by the State, therefore according to national law the children may not become the heirs of the parents if the children's' parents are concerned passed away.

Regarding one example of the Court rejecting the husband's request, stated that verdict in case 226 / Pdt.G / 2006 / PA.Amb was put forward regarding a husband who submitted a request at the Religious Court to practice polygamy, but the Court rejected the request. In the judge's consideration, among other things, to apply for a permit to polygamy, alternative and cumulative requirements must be met as stipulated in Article 4 and Article 5 of Law Number 1 of 1974 .

In this case one of the alternative conditions put forward by the Petitioner could not be proven, therefore due to the arguments not proven, the Petitioner's petition had to be rejected. The reasons put forward by the Respondent which allowed the Petitioners to practice polygamy were afraid of adultery and were not based on rights, must be put aside. On this case the Judge decided:

Reject the Petitioner's request, Punish the Petitioner to pay court fees. The refusal of the application for polygamy by the judge was based on the fact that at the time the trial was held and the wife was officially questioned by the judge and the wife denied the reasons put forward by the husband at the trial. The wife said that she was still serving her husband. This means that the reasons put forward by the husband were not proven, especially when the wife can give birth to children and did not have 
disabilities or incurable diseases. This shows that the reasons put forward by the husband are made up and unproven reasons, so it is only natural that the application for polygamy was rejected.

Apart from these reasons for applying for a permit to polygamy at the Court, the conditions as stated in Article 5 of the Law must also be fulfilled, namely:

(1) In order to submit an application to the Court, as referred to in Article 4 paragraph (1) of this Law; the following conditions must be fulfilled:

a. there is agreement from the wife / wives;

the first condition indicates that a husband who wants to marry again must be candid with his wife in expressing his desire. Because basically "Gatot Suparmono, Legal Aspects of Foreign Relationships, Djambat, Jakarta, 1998, p. 28 a wife was not willing if her husband was to get married again, so as to prevent or protect the wife from arbitrarily if the husband is getting married again. If the wife has agreed that the husband will perform polygamy, then for the husband there will be no obstacles to practice polygamy.

If only one of the three reasons stated in Article 4 paragraph (2) of the Marriage Law is proven, the Court Judge may grant the request.

In this article it is stipulated that:

(1) In the event that a husband will have more than one wife, as mentioned in Article 3 paragraph (2) of this Law, then he is obliged to submit a petition to the Court in the area where he lives.

(2) The court referred to in paragraph (1) of this article only gives permission to a husband who will have more than one wife if:

a. The wife is unable to carry out her obligations as a wife;

Referred to as being unable to carry out her obligations as a wife is a condition where the wife concerned is suffering from a physical or spiritual illness in such a way that she is unable to fulfill her obligations as a wife, both biologically and otherwise, which according to the doctor's statement is difficult to cure. This reason can be justified because in the provisions of Article 1 of the Marriage Law it is stipulated that marriage aims to form a happy and eternal family (household) therefore if the wife is unable to carry out her obligations as wife, this means that the husband's rights in the household are not fulfilled. This prevents the achievement of the goal of marriage. But what needs to be considered in assessing that the wife cannot carry out her obligations as a housewife must be related to the husband's treatment of the wife. Because there is also the possibility that the wife does not carry out her obligations as a wife due to the husband's action which only demands her rights without wanting to carry out her obligations properly. In such a case, of course, the blame cannot be placed on the wife.

b. The wife has a disability or incurable disease;

What is meant by bodily disability or incurable disease is when the wife concerned is suffering from a comprehensive body disease which, according to the doctor's statement, is difficult to cure. This reason is based solely on humanity because for the husband, of course, he will always suffer physically and mentally for his lifetime if he keeps on living together with a wife in this condition. However, on the other hand, to divorce a wife in such a way where the wife needs help from her husband is an act that is against humanity. Therefore practicing polygamy in such a case is considered more humane than pursuing monogamy by divorcing a wife who is in suffering and needs the help and protection of a husband..

c. The wife cannot bear offspring,

What is meant by not being able to give birth to offspring if the wife concerned, according to the doctor's statement, is unable to give birth, or after at least ten years of marriage it is unable to give birth.

This is a natural reason because the procreation of offspring is one of the goals of marriage itself. And for normal humans, of course they want offspring in a marriage. But the use of this reason in giving permission for polygamy, the judge must get clear information from a doctor or an expert, because the husband may experience infertility, meaning that both husband and wife are both infertile. However, if it turns out that this infertility really comes from the wife only, then this reason can be accepted.

The refusal of the application for polygamy by the judge was based on the fact that at the time the trial was held, the wife was questioned by the judge and the wife denied the reasons put forward by the husband in the trial. The wife said that she was still serving her husband. This means that the reasons put forward by the husband were not proven, especially the fact that his wife can give birth to children, and did not have disabilities or incurable diseases. This shows that the reasons put forward by the husband are made up and unproven reasons, so it is only natural that the application for polygamy was rejected. 
Apart from these reasons for applying for a permit to polygamy at the Court, the conditions as stated in Article 5 of the Law must also be fulfilled, namely:

(1) In order to submit an application to the Court, as referred to in Article 4 paragraph (1) of this Law; the following conditions must be fulfilled:

a. There is agreement from the wife / wives;

This first condition shows that the husband who wants to get married again must be candid to his wife in expressing his desire.

Because basically "Gatot Suparmono, Legal Aspects of Foreign Relationships, Djambat, Jakarta, 1998, p. 28 a wife was not willing if her husband gets married again, so as to prevent or protect the wife from the husband's arbitrariness to get married again. If the wife agrees to the husband performing polygamy, then the husband will have no obstacles to execute polygamy.

Article 5 paragraph (2) of the Marriage Law provides an exception regarding this first condition, that consent is no longer necessary for a husband if his wife / wives cannot possibly be asked for her consent and unable to be a party to the agreement. Another exception is if there is no news from his wife for at least 2 (two) years. If a wife who is asked for approval does not reject or confirm the husband's intention during this period, then the law considers that there is no need for the wife's consent.

b. There is certainty that the husband is able to provide for the living needs of his wife and children, This second requirement aims that a husband can only carry out the next marriage without paying attention to the needs of the previous family and the new family. This is in line with the goal of marriage, which is to form a happy family. The necessities of family life are not only enough to give money, but more than that the husband's affection for his wife and children is also inseparable from the necessities of family life.

c. There is a guarantee that the husband will treat his wives and children fairly. Husbands who want to get married again by law do not expect to only give priority to the new family by forgetting the previous family. The husband's biased actions are not allowed because the family will be disappointed. The husband must be able to act fairly in carrying out his role in front of his families. An assurance to act fairly in this third condition, not only on paper, meaning that a statement cannot only be in the form of a statement when you want to get married again, but it must be carried out seriously as a wise husband and father. It'd be appropriate that in his decision, the judge rejected the request for polygamy, because the requirements for the polygamy application were not fulfilled. The reasons for rejection of the polygamy petition are made if the Petitioners cannot prove the arguments of their petition. The legal basis for refusing a polygamy permit case is the failure to fulfill the provisions in Article 4 paragraph (2) of Law Number 1 Year 1974 Jo Article 41 letters a, b and c Government Regulation Number 9 Year 1975 and Articles 55, 56, 57, 58 Compilation of Islamic law. The application for polygamy was rejected because the Applicant could not prove the arguments submitted, the legal basis for its rejection was that Article 4 and Article 5 of Law Number 1 of 1974 concerning Marriage were ignored.

Thus, based on the various descriptions that have been stated, that the reason for rejecting the application for polygamy is because the Petitioner cannot confirm the arguments of his petition, both alternative reasons and cumulative reasons as stipulated in Article 4 and Article 5 of Law Number 1 Year 1974 Jo Article 57 and 58 Compilation of Islamic Law. If he was to continue to apply for polygamy again to the Court and if it is refused, then he will still live together with the unregistered marriage with the status of siri marriage.

\section{Legal Consequences of Marriage Without the Wife's Permission}

Legally, a husband who is getting married for the second, third or fourth without the permission of the first wife (former wife) is not justified and is a violation of the law. The legal consequence of a second marriage that is carried out by the husband without the permission of the first (former) wife is null and void or deemed to have never existed. This is because according to the law, Law no. 1 of 1974 concerning Marriage and Compilation of Islamic Law, if a husband wants to get married again (polygamy) then he must obtain the approval / permission of the first wife (former wife), as follows :

Article 4 paragraph 1 Law on Marriage:

"In the event that a husband will have more than one wife, as mentioned in Article 3 paragraph (2) of this Law, then he must submit an application to the Court in the area where he lives."

Article 5 Law on Marriage as follows:

(1) To be able to submit an application to the Court as referred to in Article 4 paragraph (1) of this Law; the following conditions must be fulfilled:

a. there is an agreement from the wife / wives; 
b. there is certainty that the husband is able to provide for the necessities of life of his wives and children.

c. there is a guarantee that the husband will act fairly to their wives and children. Article 55 Compilations of Islamic Law :

(1) To have more than one wife at the same time is limited to only four wives.

(2) The main requirement to have more than one wife is that the husband must be able to treat his wife and children fairly.

(3) If the main conditions mentioned in paragraph (2) cannot be fulfilled, the husband is prohibited from getting polygamy.

Article 58 Compilations of Islamic Law:

(1) In addition to the main requirements referred to in Article 55 paragraph (2), to obtain permission from the Religious Court, the conditions specified in Article 5 of Law No.1 of 1974 must also be met, namely:

a. the wife's consent;

b. there is certainty that the husband is able to provide the livelihoods of his wives and children.

So it is clear that if the husband wants to remarry he must first obtain permission from the first wife or the previous wives. If he does not get such permission, then legally the marriage would be legally flawed therefore it is null and void. (former)?

Legal sanctions for husbands who remarry (polygamy) without the permission of the first wife

The legal sanction that can be imposed on a husband who remarries without the permission of his (former) first wife is Article 279 of the Criminal Code (KUHP), with a maximum penalty of 5 to 7 years in prison.

Article 279 Criminal Code that sounds as follows:

(1) Punished with a maximum imprisonment of five years:

1. any person who enters into a marriage knowing that his existing marriage or marriages are a legal barrier to this;

2. any person who engages in a marriage knowing that the marriage or marriages of other parties are an obstacle then.

(2) If the person who commits an act based on paragraph 1 point 1 conceals to another party that the existing marriage is a legal barrier to this, he shall be punished with a maximum imprisonment of seven years.

This is also confirmed in the Supreme Court Circular No. 4 of 2016 concerning the Enforcement of the Formulation of the Plenary Meeting Results of the Supreme Court Chamber of 2016 as Guidance for the Implementation of Court Duties which states:

"Whereas a marriage which is entered into by a husband with another woman while the husband does not have the wife's permission to remarry, Article 279 of the Criminal Code can be applied."

Thus, if a husband who is still married but marries another woman without the permission of his first wife or previous wife, he can be subject to Article 279 of the Criminal Code with imprisonment..

\section{Closing}

\section{CONCLUSION}

1. In essence there is a principle of marriage according to Law Number 1 of 1974 concerning Marriage, adhering to the principle of monogamy, however, if the person wishes so, because the law and religion of the person concerned allows it, a husband can have more than one wife. However, a marriage between a husband and more than one wife, even though it is desired by the parties concerned, can only be carried out if certain conditions are met and decided by the Court. According to Law No.1 of 1974, polygamous marriages are permitted and even if desired by the parties concerned can only be done if certain conditions are met and decided by the court. Permission from the Court is a requirement that must be met so that a husband can practice polygamy and the marriage can be registered with the Marriage Registry Officer. However, if there is no permission from the Court of a husband to continue to practice polygamy, the marriage cannot be registered at the Marriage Registration Office and this marriage is commonly referred to as a siri marriage or an underhand marriage. Marriages carried out in siri cannot prove that there has been a marriage because they do not have proof of marriage, namely a Marriage Certificate.

2. If a husband who is still married but marries another woman without the permission of his first wife or previous wife, he may be subject to Article 279 of the Criminal Code with the threat of imprisonment. 


\section{Suggestion}

Law No.1 of 1974 concerning Marriage, especially the regulations governing the requirements for polygamous marriage, needs to be further enhanced so that society, especially women, can avoid the consequences of not having a marriage certificate in marriage..

\section{REFERENCES}

Abdullah Kelib, 1990, Islamic Law, Tugu Muda, Semarang

A. Rahman I Doi, 1996, Characteristics of Islamic Law and Marriage, Srigunting, Jakarta

Ahmad Rofiq, 1998, Islamic Law in Indonesia, Rajawali, Jakarta.

Ariij Binti Abdur Rahman As-Sanan, 2006, Fair Against Wives, Darus Sunnnah Press, Jakarta

K. Wantjik Saleh, 1990, Indonesian Marriage Law, Ghalia Indonesia, Jakarta

Mohd, Idris Rainulyo, 4999, Islamic Marriage Law, Bumi Aksara, Jakarta

Musdah Mulia, 1999, Islamic Views on Polygamy, Institute for the Study of Religion and Gender, Jakarta

R. Abdul Djamali, 1992, Islamic Law, Mandar Maju, Bandung

Suryono Sukanto, 1986, Normative Legal Research, Rajawali, Jakarta 